\title{
Factors Correlated With Quality Of Patient's Handover In Inpatient Room Of The Hospital
}

\author{
Wiwin Sulistyawati, Arif Nurma Etika, Restu Novitasari \\ Universitas Kadiri Kediri, Indonesia \\ Corresponding author : wiwin.sulistyawati86@gmail.com
}

\begin{abstract}
Background: Communication failure during handover is the main cause of the patient's injury and is the root cause of $65 \%$ of the sentinel incident. Bad handover is assumed to have correlation with clinical diagnosis inaccuracies, delay in diagnosis, delay in laboratory tests, treatment errors, inconsistent or misinterpretation of results, duplication of tests, increase in complications of the Hospital.
\end{abstract}

Purpose: This study aimed to determine the factors related to the quality of the patient's handover in inpatient room of the hospital.

Methods: This research used a correlational analysis study with a cross sectional approach. Data retrieval use questionnaires and observation sheets. The number of samples on this study is 79 nurses taken in random sampling techniques. Statistical analysis used is a test of spearman rank.

Results: The result of this research revealed that most of the respondents $(69.6 \%)$ are diploma graduates, and $72.2 \%$ of respondents have a working time of $<5$ years. Almost all respondents $(93.7 \%)$ have good motivation, and $94.9 \%$ of respondents have good handover quality. The last educational variable $(\mathrm{p}=0.388)$ and the nurse's working time $(\mathrm{P}=0.209)$ are not related to the quality of the handover, while the motivation $(\mathrm{P}=0.000)$ and the implementation of the chief nurse's supervision $(\mathrm{P}=0.000)$ relate to the quality of the handover between the shifts in the inpatient room of the hospital.

Conclusion of this study is the motivation and the implementation of the chief nurse's supervision relate to the quality of the handover between the shifts in the inpatient room of the hospital. Hospital's management is expected to raise the motivation of nurses in conducting handover and enhancing the supervision of the chief nurse to improve the quality of the patient's handover and minimize the errors in information exchange conducted by nurses.

Keywords: Handover, Education Level, Motivation, Nurse, Supervision Of The Chief Nurse 


\section{BACKGROUND}

Nursing Handover becomes a priority research for the safety of patients and all parties strive to improve Handover communication (Smeulers, M., Lucas, C., Vermeulen, 2014). Handover is one of the techniques for providing information to the nursing team at the time of the change of service, and it is a guide to practice in providing information on the latest patient conditions, treatment goals, patient care plans and determining service priorities (Rushton, 2010).

Communication failure during handover is the main cause of the patient's injury and is the root cause of $65 \%$ of the sentinel incident (Joint Commission International, 2011). Bad handover is assumed to have correlation with clinical diagnosis inaccuracies, delay in diagnosis, delay in laboratory tests, treatment errors, inconsistent or misinterpretation of results, duplication of tests, increase in complications of the Hospital, increase in treatment period and lower patient and employee satisfaction (Smeulers, M., Lucas, C., Vermeulen, 2014).

Based on the results of preliminary data by conducting interviews with nursing department in inpatient room hospital X Kediri in November 2018, it was concluded that the implementation of handover was not optimal. Perceptions of nurses were varied in term of handover and not yet available SOP (standard operational Procedures) concerning with the implementation of handover in every room.

Hughes, R (2008) mentioned that individual factors, groups, and organizations affect the process of handover of the patient. Factors of knowledge, attitude, availability of SOP, leadership and associates significantly affect the handover. The knowledge factor is the most influential factor towards handover. (Kullberg, 2018).

Based on the background above, the researchers want to conduct research on the analysis of factors that affect the quality of handover in the inpatient room of hospital $\mathrm{X}$ in Kediri.

\section{OBJECTIVE}

This study aimed to determine the factors related to the quality of the patient's handover in inpatient room of the hospital

\section{METHODS}

The design of this research is correlational analytic with a cross-sectional approach. The population of this study is 99 executive nurses in inpatient room. This research sample is 79 nurses taken using simple random sampling. Independent variables in this study are variable level of education, working period, supervision of the chief nurse, and motivation. Dependent variable is handover. Research instrument for variable level, education, working period, supervision of the chief nurse, and motivation is questionnaires. Meanwhile, handover uses the observation sheet. Statistical analysis uses Spearman test.

\section{RESULT}

Tabel 1. Characteristics of total respondents based on gender, age, and education of nurses at hospital X in 2019.

\begin{tabular}{lll}
\hline Variable & $\begin{array}{l}\text { Frequenc } \\
\text { y }\end{array}$ & $\begin{array}{l}\text { Percentag } \\
\text { e }\end{array}$ \\
\hline Gender & & \\
Male & 23 & 29,1 \\
Female & 56 & 70,9 \\
Age & & \\
\hline
\end{tabular}




\begin{tabular}{lll}
\hline $20-30$ years old & 67 & 84,8 \\
$31-40$ years old & 12 & 15,2 \\
$>40$ years old & 0 & 0 \\
Last Education & & \\
Diploma & 55 & 69,6 \\
Ners & 24 & 30,4 \\
Working Period & & \\
$<5$ years & 57 & 72,2 \\
5-10 years & 20 & 25,2 \\
$>10$ years & 2 & 2,5 \\
\hline
\end{tabular}

Tabel 2. Characteristics of respondents based on motivation, supervision, and handover quality of nurses at hospital X in 2019.

\begin{tabular}{lll}
\hline Variable & Total & Percentage \\
\hline Motivation & & \\
Poor & 0 & 0,0 \\
Fair & 5 & 6,3 \\
Good & 74 & 93,7 \\
Supervision & & \\
Poor & 6 & 7,6 \\
Good & 73 & 92,4 \\
Handover Quality & & \\
Poor & 0 & 0,0 \\
Fair & 4 & 5,1 \\
Good & 75 & 94,9 \\
\hline
\end{tabular}

Based on table 2, almost all (93.7\%) respondents have good motivation in doing handover, $92.4 \%$ of the nurses are well-supervised by the head of the room, and $94.9 \%$ of respondents carried out handover properly.

Tabel 3. Cross tabulation of the relationship of last education with Handover quality at hospital X year 2019.

\begin{tabular}{llll}
\hline Last Education & \multicolumn{3}{l}{ Handover Quality among Shifts } \\
& Good & Fair & Total \\
\hline Diploma & 53 & 2 & 55 \\
& $(67,1 \%)$ & $(2,5 \%$ & $(69,6 \%)$ \\
\multirow{2}{*}{ Ners } & 22 & ) & \\
& $(27,8 \%)$ & $(2,5 \%$ & $(30,4 \%)$ \\
& & ) & \\
\hline Total & 75 & 4 & 79 \\
& $(94,9 \%)$ & $(5,1 \%$ & $(100 \%)$ \\
& & ) & \\
\hline P Value $=0,388 *$ & $\mathrm{R}=-0,099 *$ & \multicolumn{3}{c}{$\alpha=0,05$} \\
\hline
\end{tabular}

Based on table 3, $\rho$ value $=0.388>\alpha=0.05$, then Ho is accepted and H1 is rejected. It means there is no relationship between the last education and the quality of handover among shifts at the hospital hospital X in 2019. 
Tabel 4. Cross tabulation of relationship of working period with Handover quality among shifts at inpatient room of hospital in 2019.

\begin{tabular}{llll}
\hline Working Period & \multicolumn{3}{l}{ Handover Quality among Shifts } \\
& Good & Fair & Total \\
\hline$<5$ years & 55 & 2 & 57 \\
& $(69,6 \%$ & $(2,5 \%$ & $(72,2 \%)$ \\
5 5-10 years & 19 & 1 & \\
& $(24,1 \%$ & $(1,3 \%$ & $(25,3 \%)$ \\
& ) & ) & \\
$>10$ years & 1 & 1 & 2 \\
& $(1,3 \%)$ & $(1,3 \%$ & $(2,5 \%)$ \\
& & ) & \\
\hline Total & 75 & 4 & 79 \\
& $(94,9 \%$ & $(5,1 \%$ & $(100 \%)$ \\
\hline P Value $=0,209 *$ & $\mathrm{R}=-0,143 *$ & \\
\hline
\end{tabular}

Based on table 4, the result of Spearman test is $\rho$ value $=0.209>\alpha=0.05$, then Ho is accepted and $\mathrm{H} 1$ is rejected. It means there is no relationship between working period and the quality of the handover among shifts at inpatient room in the hospital in 2019.

Tabel 5. Cross tabulation of relationship of motivation with Handover quality among Shifts at inpatient room of the hospital in 2019.

\begin{tabular}{|c|c|c|c|}
\hline \multirow[t]{2}{*}{ Motivation } & \multicolumn{3}{|c|}{$\begin{array}{l}\text { Handover Quality among } \\
\text { Shifts }\end{array}$} \\
\hline & Good & Fair & Total \\
\hline Good & $\begin{array}{l}74 \\
(93,7 \%)\end{array}$ & $\begin{array}{l}0 \\
(0,0 \% \\
)\end{array}$ & $\begin{array}{l}74 \\
(93,7 \%)\end{array}$ \\
\hline Fair & $\begin{array}{l}1 \\
(1,3 \%)\end{array}$ & $\begin{array}{l}4 \\
(5,1 \% \\
)\end{array}$ & $\begin{array}{l}5 \\
(6,3 \%)\end{array}$ \\
\hline Total & $\begin{array}{l}75 \\
(94,9 \%)\end{array}$ & $\begin{array}{l}4 \\
(5,1 \% \\
)\end{array}$ & $\begin{array}{l}79 \\
(100 \%)\end{array}$ \\
\hline
\end{tabular}

Based on table $5 \rho$ value $=0.000<\alpha=0.05$, then Ho is rejected and H1 is accepted. It means there is a relationship between the motivation and the quality of the handover among shifts at inpatient room in the hospital $X$ in 2019. With a coefficient value of correlation $\mathrm{r}=0.888$, the strength of the relationship can be concluded very strong. Direction of linear relationship (+) which means better nurse motivation, better handover quality among shifts will be

Tabel 6. Cross tabulation of relationship of supervision of chief nurse with Handover quality at hospital X in 2019.

\begin{tabular}{llll}
\hline Supervision of Chief Nurse & \multicolumn{3}{l}{ Handover Quality among Shifts } \\
& Good & Fair & Total \\
\hline Good & 73 & 0 & 73
\end{tabular}




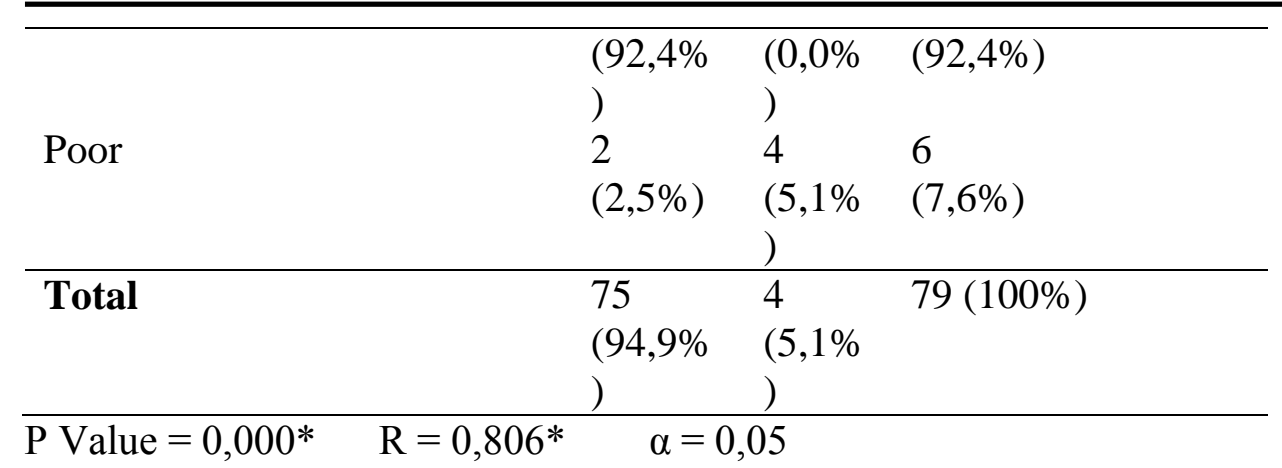

Table 6 shows that $\rho$ value $=0.000<\alpha=0.05$, then Ho is rejected and H1 accepted. There is a significant relationship between the supervision of the chief nurse and the quality of the handover among shifts in hospital $X$ in 2019. With a coefficient value of correlation $\mathrm{R}=0.806$, it can be inferred that the relationship is very strong. Direction of linear relations $(+)$ which means better supervision of the chief nurse, better handover quality among shifts will be.

\section{DISCUSSION}

\section{Relationship between Last Education and Handover Quality}

Table 3 shows $67.1 \%$ of Diploma-Nurses have a good quality of handover among shifts, rather than the Ners-nurses $(27.8 \%)$. The result shows that there is no relationship between the last education and the quality of handover among shifts in hospital X Kediri.

The result of this research is in accordance with previous research that there is no relationship between education level (vocational and professional) and the performance of nurses to the obedience of conducting SOP (Nazvia, 2014).

At the first time of the nurse workday, they will be directed to perform of how to have an information exchange properly. Considering that handover is the nurses routine in every shift-exchange, it must be handled precisely in order to avoid any errors in conducting handover itself. This direction brief can enhance nurse performance in conducting information exchange. Moreover, information exchange conducted repeatedly will enhance nurse skill in doing handover. Thus, in this research, there is no relationship between education level and handover quality.

\section{Relationship between Working Period and Handover Quality}

The result shows that there is no meaningful relationship between the working period and the quality of the handover shifts in the inpatient room.

The result is similar to (Zahara, Sitorus, and Sabri, 2011) stating that there is no meaningful relationship between working period and performance. Handover is the activity of delivering information about the patients in every shift exchange. Something that is done repeatedly will make nurses become proficient in doing handover. In conducting a good handover, nurse does need much time or even years.

\section{Relationship between Motivation and Handover Quality}

The result of the study is gained a significant relationship between motivation and quality of handover among shifts in the inpatient room. Table 5 shows that $93.7 \%$ of good motivation also has a good quality of handover among shifts. The research is in line with (Sulistyawati, 2018) stating that there is a relationship between nurse motivation and handover quality with strong relationship.

Motivation is the accumulation of various processes that affect and direct the individual's behavior to achieve certain objectives (Negussie, 2012). Work motivation is a very relevant factor that affects the quality of performance, especially in the health sector (Toode, Routasalo, and Suominen, 2011). 
In this research, generally, nurses are motivated and their working performance in conducting their information exchange is good. The nurses simply agree that conducting handover is their responsibility in which they are granted an authority so that they will pay much attention on their outcome.

Good communication is a sort of communication that is able to empower as well as involve the family. It becomes a very crucial thing in giving family centered care. Enhancing quality and quantity are proved in giving advantage to patient treatment, patient satisfactory, and patient's family (Zhu, 2014).

\section{Relationship between Chief Nurse Supervision and Handover Quality}

The result of the Spearman test shows that there is a relationship between the supervision of the chief nurse and the handover quality among shifts in hospital X.

The result of this study is in line with stating that the most dominant factor affecting working performance is supervision. Nurse who has good supervision will have better working performance 72.952 times more than the nurse who has lack of supervision. (Zahara, Sitorus, and Sabri, 2011).

It is also in accordance with (Sulistyawati, 2016) stating that the function of direction and controlling brief from chief nurse has a significant relationship on the implementation of discharge planning.

The quality of nursing care in patients will be assured when supervision is conducted in accordance with established guidelines. Good supervision will increase the motivation of nurses who have an impact on improving the performance of nurses (Zahara, Sitorus, and Sabri, 2011).

The supervision of SBAR communication affects the quality of handover in Melati and Bougenvil room of hospital $\mathrm{X}$ in Blitar. SBAR supervision is one of the ways to improve patient safety and reduce the occurrence of errors caused by communication failures (Sulistyawati \& Haryuni, 2019).

\section{CONCLUSION and SUGGESTION Conclusion}

From the results of the study, it can be concluded that nurses are mostly graduated from diplomas and have working period for $<5$ years. Almost all respondents have good motivation, good perception on the implementation of the supervision of the chief nurse and good quality handover.

Result of bivariate analysis shows that; last education and working period are not related to the quality of handover. However, there is a meaningful relationship between the motivation of nurses with the quality of the handover among shifts within a strong relationship and the direction of the relationship (+), and there is a relationship between Implementation of the supervision of the chief nurse with a quality handover within a strong relationship and direction of the relationship (+).

\section{Suggestion}

It is hoped that the field of nursing could give supervision and motivation periodically to improve the quality of handover. 


\section{REFERENCES}

Hughes, R. (Ed.). (2008). Patient safety and quality: An evidence-based handbook for nurses (Vol. 3). Rockville, MD: Agency for Healthcare Research and Quality.

Joint Commission. (2011). Sentinel Event Data Event Type by Year 1995-2015.

Kullberg, A., Sharp, L., Dahl, O., Brandberg, Y., \& Bergenmar, M. (2018). Nurse perceptions of person-centered handovers in the oncological inpatient setting: A qualitative study. International journal of nursing studies, 86, 44-51. https://doi.org/10.1016/j.ijnurstu.2018.06.001

Nazvia, N., Loekqijana, A., \& Kurniawati, J. (2014). Faktor yang mempengaruhi kepatuhan pelaksanaan SOP asuhan keperawatan di ICU-ICCU RSUD Gambiran Kota Kediri. Jurnal Kedokteran Brawijaya, 28(1), 21-25. http://dx.doi.org/10.21776/ub.jkb.2014.028.01.17

Negussie, N. (2012). Relationship between rewards and nurses' work motivation in Addis Ababa hospitals. Ethiopian journal of health sciences, 22(2).

Rushton, C. H. (2010). Ethics of nursing shift report. AACN advanced critical care, 21(4), 380-384. https://doi.org/10.4037/NCI.0b013e3181ef8648

Smeulers, M., Lucas, C., \& Vermeulen, H. (2014). Effectiveness of different nursing handover styles for ensuring continuity of information in hospitalised patients. Cochrane Database of Systematic Reviews, (6). https://doi.org/10.1002/14651858.CD009979.pub2

Sulistyawati, W., \& Haryuni, S. (2018). Hubungan Motivasi Perawat dengan Kualitas Handover Pasien di Ruang Rawat Inap Rumah Sakit. Jurnal Ilmiah Keperawatan, 13(2). https://doi.org/10.30643/jiksht.v13i2.9

Sulistyawati, W. (2016). Implementasi Fungsi Manajemen Dalam Pelaksanaan Discharge Planning. JURNAL ILMIAH KEPERAWATAN, 889.

Sulistyawati, W., \& Haryuni, S. (2019). Supervisi tentang Komunikasi SBAR (Situation, Background, Assesmen and Recommendation) Berpengaruh terhadap Kualitas Handover Pasien di Ruang Rawat Inap Rumah Sakit. Care: Jurnal Ilmiah Ilmu Kesehatan, 7(1), 19-26. https://dx.doi.org/10.33366/jc.v7i1.1111

Toode, K., Routasalo, P., \& Suominen, T. (2011). Work motivation of nurses: A literature review. International journal of nursing studies, 48(2), 246-257. https://doi.org/10.1016/j.ijnurstu.2010.09.013

Zahara, Y., Sitorus, R., \& Sabri, L. (2011). Faktor-Faktor Motivasi Kerja: Supervisi, Penghasilan, dan Hubungan Interpersonal Mempengaruhi Kinerja Perawat Pelaksana. Jurnal Keperawatan Indonesia, 14(2), 73-82.

Zhu, H., McCrea, N., \& Kelsall, W. (2014). G188 Improving the paediatric handover: quality, safety and SBAR. Archives of Disease in Childhood, 99(Suppl 1), A82-A82. http://dx.doi.org/10.1136/archdischild-2014-306237.192 